\title{
An Assessment of the Water, Irrigation, and Food Security by a Fishbone Analysis in Turkey
}

\author{
A. Ahmet Yücer ${ }^{1}$, Feyza Nur Ayhan² \\ ${ }^{1}$ Ministry of Agriculture and Forestry, Ankara, Turkey \\ ${ }^{2}$ Graduate School of Social Sciences, Çankırı Karatekin University, Çankırı, Turkey \\ Email: ayucer06@gmail.com, feyzaayhan94@gmail.com
}

How to cite this paper: Yücer, A.A. and Ayhan, F.N. (2020) An Assessment of the Water, Irrigation, and Food Security by a Fishbone Analysis in Turkey. Open Access Library Journal, 7: e6929. https://doi.org/10.4236/oalib.1106929

Received: October 25, 2020

Accepted: November 24, 2020

Published: November 27, 2020

Copyright () 2020 by author(s) and Open Access Library Inc.

This work is licensed under the Creative Commons Attribution International License (CC BY 4.0).

http://creativecommons.org/licenses/by/4.0/

(c) (i) Open Access

\begin{abstract}
The use of water resources is ineffective although Turkey has insufficient freshwater resources. Dry farming is practiced in a large part of agricultural land. This land due to insufficient precipitation throughout the country is left to fallow once in two years. Agricultural drought is becoming a severe challenge for agriculture and food security, and it may also impact the wealth of farmers by agriculture income. So, it causes widespread concern among the rural population. There is a close relationship between food security and agricultural irrigation. Ensuring food security against population increase is the main responsibility of the government via irrigation policies. Basically, these policies are divided into two as expanding irrigated areas and improving efficiency in irrigation by new irrigation investments. These are water transfer from reservoirs to dry agricultural areas and improve pressurized irrigation investment. Significant efforts have been made by governments since the 1960s to reduce the risk of drought in agricultural production and to increase agricultural yields. Increasing agricultural income through irrigation and satisfying small family businesses are among the political goals of governments. However, according to the findings of this study, as the development priorities of governments changed after 2003, the share of irrigation investments in the total budget gradually decreased. Although great targets have been set for 2023, it seems difficult to reach these targets since sufficient resources are not allocated to irrigation investments. In this study, the current state of irrigation and its effects on food security were analyzed with a literature review and Ishikawa diagram, and the policies implemented by the government and relevant government agencies were evaluated. The article mainly deals with the current state of irrigation and food security targets.
\end{abstract}

\section{Subject Areas}

Agricultural Science, Ecology, Environmental Sciences 


\section{Keywords}

Precipitation, Climate Change, Water, Irrigation, Food Security

\section{Introduction}

The feeding of the world's growing population will depend heavily on water resources. However, the future of water resources will be determined by the increasing water demand of other sectors, deterioration of water quality, and declining groundwater levels [1]. The critical balance among the limited water, soil, and plant resources that are seen in most of the regions in the world necessitates important strategies for sustainable agriculture. Water resources in sufficient quantity and appropriate quality are essential to ensure food production and food security [2]. Irrigation need arises from a lack of rainfall in dry agricultural areas. Ensuring food security is the main development goal largely linked to the expansion of irrigated agricultural land [3].

In terms of sustainable agricultural production, food security, and rural development in developing countries, governments, and policymakers have shown a lot of interest in improving irrigation infrastructure [4]. Access to water directly increases the amount of agricultural production and farm incomes, as it increases productivity in all crops. A strong relationship has been found between crop income and irrigation in rural areas [5]. It is estimated that $25 \%$ of the African population (about 200 million people) still suffers from water shortages. Water stress remains one of the biggest challenges in ensuring food security. It is predicted that more countries will face water and food insecurity in the future. In addition, radical changes are needed in agricultural production systems in order to reduce the negative effects of climate change and to ensure adaptation. Technological and political practices that provide science-based solutions will enable farmers to better manage the land, the environment, and food security [6].

Food security depends on water resources contributing more than $40 \%$ to production [7]. In some countries of the world, the effect of irrigation systems on food production reaches $50 \%-80 \%$ [8]. According to rain-based production, irrigation increases crop yields and can double agricultural productivity by expanding the plant-growing season [9]. In a study conducted in Indonesia, North Sumatra, the role of the irrigation system in rice production and supporting food security was calculated to be $64.64 \%$ on average [8].

According to a study conducted in India; $46 \%$ (64.6 m ha) of approximately $140 \mathrm{~m}$ ha of cultivated land is irrigated. While previously irrigable areas were determined depending on the slope of the land, today all kinds of land can be irrigated thanks to smart irrigation technologies. With the decrease in water resources in the future, the agricultural sector will be under great pressure in terms of providing food, feed, and raw materials. There is an urgent need for political 
intervention in irrigation water management and the adoption of smart irrigation technologies for food security [10].

Agricultural investments in China have formed the basis for agricultural growth and transformation. Despite public resource constraints, the Chinese government has allocated more resources to agricultural investments (land regulation, irrigation, and agricultural technologies) than general financial expenditures after the mid-2000s through the Ministry of Agriculture. The irrigated agricultural land expanded from $45 \mathrm{~m}$ ha to $67 \mathrm{~m}$ ha in the period of 1978-2016 and 50\% of the cultivated land became irrigable. Irrigation investments improved soil quality of low and medium quality land and contributed to the development of agricultural production capacity [11]. In Australia, where most of the agricultural land is under the effect of severe drought, serious losses have occurred in its production. Wheat production was $50 \%-60 \%$ below the average for two consecutive years (2005-06) due to drought, and it significantly affected world prices [12].

The average yield of irrigated land can be five times that of dry farming land and the average value-added per irrigated hectare is 2.6 times that of one rainfed hectare [13].

In a study conducted in Tanzania; It has been determined that the Water User Association needs capacity building and continuous institutional support, and managers do not have control mechanisms in terms of authority and responsibility. In local associations, all members should not be expected to have the willingness to manage the association or to finance the services they receive, or to achieve a sense of responsibility and ownership [14]. Water supply is arguably one of the most politicized public services in developing countries [15]. Turkey especially in energy and irrigation investments has affected the management of the country itself, "King of Dams" identifies a politician who has become the most important political figure of the country during the period 1965-2000 [16].

As a result, irrigation, which is one of the most important inputs of agricultural production, will enable the agricultural sector to get rid of the dependence on climatic conditions, diversify the production, increase the use of fertilizers, extend the plant growing period, increase the productivity per unit area, increase the income of the farmers and food security [17]. In this study, Turkey's water potential, the current status of irrigation, aims to demonstrate the contribution of irrigation and food security objectives.

\section{Material Method}

In this study, a policy analysis on water resources, irrigation, and food security has been tried to be made and examined the effect of the expansion of irrigated areas on agricultural production. Government policy documents, organizations' strategies, goals, projects, workshop reports, and institutional records on the effects of irrigation on food security were collected and analyzed. The literature review was compiled by scanning keywords from published research articles by 


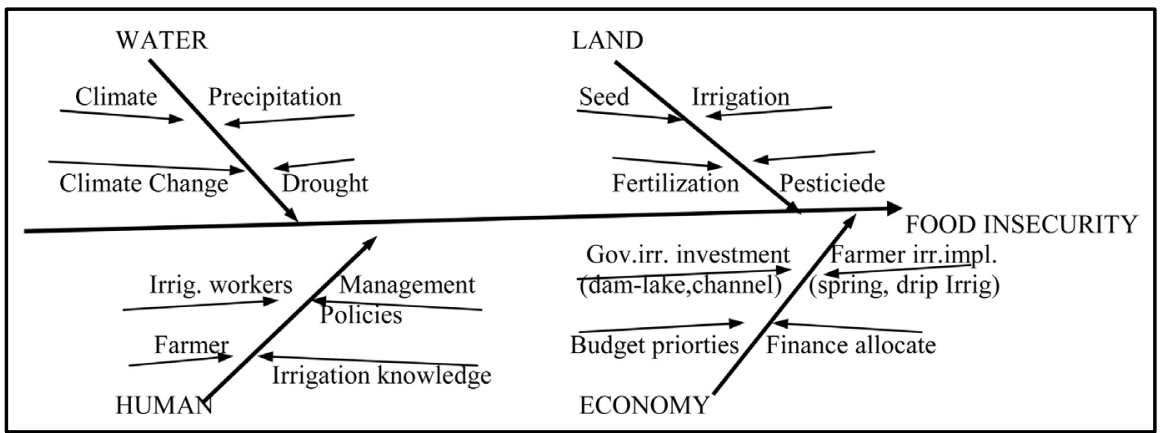

Figure 1. Cause and effect analysis in Ishikawa diagram.

universities and research institutes.

Scientific data on irrigation and food safety were classified based on data mining, tables and figures were created and interpreted. In addition to time-series data, different statistical methods such as mean and percentage were used to obtain meaningful findings in the study. Turkey's water potential, the possible effects of climate change, the current status of irrigation, irrigation objectives, and its impact on food safety has been evaluated.

In order to analyze the causes of food insecurity, the fishbone diagram (also known as the Ishikawa diagram) was used to identify and group the causes that make up a problem. The causes of the problem were analyzed by dividing them into main and subcategories. In the cause and effect analysis; problem determination, data collection, determination of probable causes, identification of the root cause, proposal of the activities to be carried out have been completed [18]. The diagram provides a comprehensive view of food security across key problem areas. Sub-titles directly related to irrigation in every problem area, climate, climate change, water potential, irrigation policies, investment projects and their effects on food security were examined.

Also known as a cause and effect diagram, the diagram is a chart that regularly categorizes many potential causes in a problem (Figure 1).

\section{Climate and Climate Change}

Turkey, located between 26 - 45 and 36 - 42 north latitude and east longitude. It has a total surface area of $78 \mathrm{~m}$ ha. It is surrounded by seas (Black Sea, Aegean Sea, and the Mediterranean Sea) on three sides and by Bulgaria, Greece, Syria, Iraq, Iran, Azerbaijan, and Armenia. Since there are many high mountains and high plateaus in the country, its average altitude is approximately $1132 \mathrm{~m}$ and 3.5 times that of Europe. Mountains stretching parallel to the sea, sudden topographic differences cause climate change at short distances [17].

\subsection{Climate Types}

Turkey $574 \mathrm{~mm}$ average rainfall for many years (below the world average of 800 $\mathrm{mm}$ ) and has a semi-arid climate. Average annual precipitation rates by regions can be seen in Figure 2. In Central Anatolia, annual precipitation drops to 250 


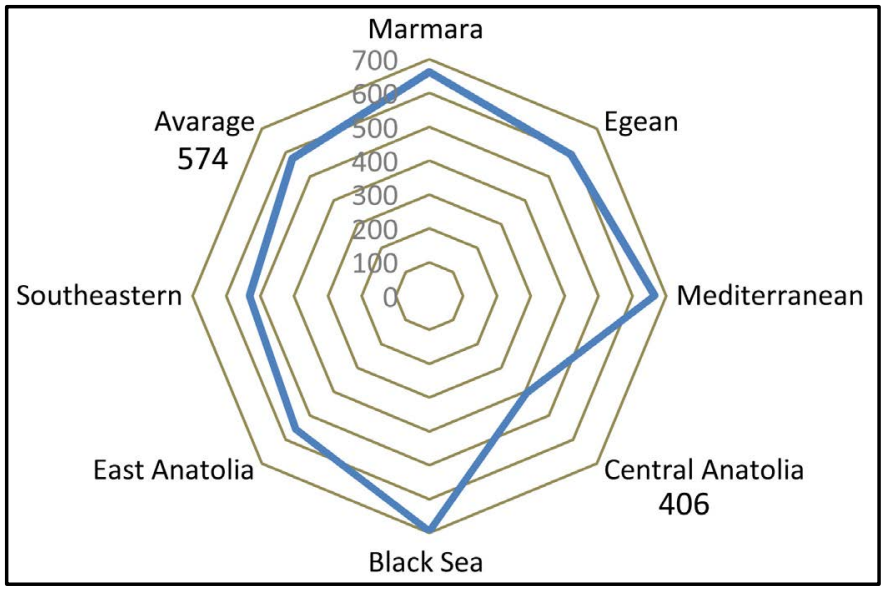

Figure 2. Average annual precipitation by region ( $\mathrm{mm})$.

$\mathrm{mm}$ in the south of Lake Tuz and up to $2500 \mathrm{~mm}$ on the Eastern Black Sea coast. The lowest average precipitation occurs in the Central Anatolia region with 406 $\mathrm{mm}$, and the highest average precipitation occurs in the Black Sea region with $696 \mathrm{~mm}$.

Four climate types are observed in Turkey's geography. These are Terrestrial, Mediterranean, Marmara (transition), and Black Sea climate. The Terrestrial climate is observed in $60 \%$ of the total area, including Central, Eastern, Southeastern Anatolia, and a part of Thrace. In this climate, precipitation is usually in the spring and winter months. Irregular and drought prevail during the plant development period.

The Mediterranean climate is effective in the south-facing parts of the Taurus Mountains in the Aegean Region and the Mediterranean Region. The summer season is hot and dry, and the winter season is warm and rainy. The Black Sea climate is effective in the coastal parts of the Black Sea Region and on the northern slopes of the mountains. It is rainy every season. Winters are cool on the coastal area, snowy and cold in the higher parts. Marmara (transition) climate is seen in the Marmara Region and the North Aegean region. It is a transition between the Black Sea and Mediterranean climates [19].

\subsection{Climate Change}

In the Intergovernmental Panel on Climate Change (IPCC) Fourth Assessment Report, it is stated that the general temperature increase in the Mediterranean Basin will reach $2^{\circ} \mathrm{C}$ and the number of droughts, heatwaves, and extremely hot days will increase. In Turkey, the average annual temperature will be an increase between $2.5^{\circ} \mathrm{C}$ and $4^{\circ} \mathrm{C}$ in the near future, and this increase is expected to be $5^{\circ} \mathrm{C}$ in Central Anatolia. It is stated that until the middle of the century, it is believed that many semi-arid regions (including the Mediterranean Basin) will experience a decrease in water resources due to climate change. The annual river flow and water availability will decrease in the Mediterranean Basin. Sectors affected by drought will include agriculture, water supply, energy production, and health. 
Regionally, large increases in irrigation water demand are predicted as a result of climate changes. Besides this report, other national and international scientific studies, Turkey's near future warmer, arider and shows rainfall will be more uncertain. Researches suggest increased temperatures will also affect the physical, chemical, and biological properties of freshwater lakes and rivers, with predominantly adverse impacts on many individual freshwater species, community composition, and water quality [20].

The increment rate in the water requirements due to the population increase, global warming, and climate change negatively affect the water resources especially water used in agriculture. In addition, the decrease in precipitation and the increase in temperature, due to global warming, will change the types of land and water use [21]. Changes in precipitation and temperature in Turkey will affect water resources, agricultural production, human health, natural disasters, and economic growth. It can be said that the ECHAM5 simulation points to two regions where significant changes will occur in precipitation. These regions are the Mediterranean and Southeastern Anatolia, where precipitation is supposed to decrease significantly after 2040, and the Black Sea Regions, where precipitation is predicted to increase [22]. Therefore, as for food security and water management, "National Water Plan 2019-2023" and "National Climate Change Action Plan 2011-2023" have been prepared by the Ministry of Agriculture and Forestry [23], and Ministry of Environment and Urbanization [24]. In these documents, strategic targets and actions have been determined. The Turkish Government has adopted an approach based on the watershed for the preparation of river basin protection and management plans. The World Bank (WB) has been supporting these efforts in different ways [25].

\subsection{Political Framework}

Turkey's water policies are determined by various legal regulations. These policies are implemented by various ministries and executive units [26]. Turkey's water policies are characterized by a desire to achieve energy independence, ensure food security through increased agricultural production, and to meet the demand for water of other sectors [27]. According to the Constitution of the Republic of Turkey (Art. 168), to develop and manage water resources, belong to the state authority. According to the Turkish Civil Code (Art. 756), surface and groundwater resources cannot be private property, except for springs from private land. However, there are user rights for irrigation, fishing, thermal, energy, industry, mining, domestic use, etc. State Hydraulic Works (SHW) gives water use permits in Turkey [26].

The main purpose is to improve water and soil resources in Turkey SHW, in the year 1953 (6200 Law No.) has been established and organized along 25 major river basins in the country. It acts as the competent authority in the planning, implementation, and management of water investments. Among the duties of SHW, are dams, irrigation canals, and the construction of flood prevention bar- 
riers, drying of swamps, and supplying drinking water to big cities [17].

General Directorate of Land and Water (Soil-Water), which was established in 1960 (law no 7457), was transferred to the General Directorate of Rural Services (KHGM) in 1985. In 2005, as part of the government's decentralization program, KHGM was abolished (Law No. 5286), and its duties regarding land and water affairs were transferred to the Special Provincial Administrations-SPAs (Law No. 5302). Before this date, large irrigation investments were made by SHW, and small irrigation investments of less than 500 liters per second were made by Toprak-Su and later by KHGM [26]. However, with the transfer of this duty to the Special Provincial Administrations, a gap has arisen in this regard, but the government has not made regulations on this issue yet.

\section{Water Resources}

According to the "World Water Development Report" prepared by UNESCO, Turkey takes 45th place in the world as of freshwater resources. The annual amount of water per person is $1493 \mathrm{~m}^{3}$. Considering the population of the country to reach 85 million by 2030 and water resources to decrease gradually, it is estimated that this amount will decrease to $1100 \mathrm{~m}^{3}$ [21]. When taken into account the impacts of the factors like the existing development rate, changes in water consumption habits, it is likely to predict the possible pressures such as much demand on the water resources [28].

The annual average precipitation amount in Turkey is about $574 \mathrm{~mm}$ and this corresponds to 448 billion $\mathrm{km}^{3}$ of water (Table 1). More than half, around 246

Table 1. Water resources potential of Turkey.

\begin{tabular}{lcc}
\hline \multicolumn{1}{c}{ Annual Average Precipitation $\left(\mathrm{mm} / \mathrm{m}^{2}\right)$} & 574 & $(\%)$ \\
\hline Annual Precipitation Amount $\left(\right.$ billion $\left.\mathrm{km}^{3}\right)$ & 448 & 100 \\
- Evaporation $\left(\right.$ billion $\left.\mathrm{km}^{3}\right)$ & 246 & 54.9 \\
- $\quad$ Leakage to Underground $\left(\right.$ billion $\left.\mathrm{km}^{3}\right)$ & 63 & 14.0 \\
- $\quad$ Annual Runoff $\left(\right.$ billion $\left.\mathrm{km}^{3}\right)$ & 140 & 31.1 \\
- $\quad$ Usable springs Water $\left(\right.$ billion $\left.\mathrm{km}^{3}\right)$ & 25 & \\
- $\quad$ Water from neighbor countries $\left(\mathrm{billion} \mathrm{km}^{3}\right)$ & 6 & \\
- $\quad$ Gross surface water potential $\left(\right.$ billion $\left.\mathrm{km}^{3}\right)$ & 171 & 90.5 \\
Withdrawable water from underground $\left(\mathrm{billion} \mathrm{km}^{3}\right)$ & 18 & 9.5 \\
Renewable gross water potential $\left(\right.$ billion $\left.\mathrm{km}^{3}\right)$ & 189 & 100 \\
Economic \& technical usable water potential $\left(\mathrm{billion} \mathrm{km}^{3}\right)$ & 100 & \\
Total Usage (billion km $\left.{ }^{3}\right)$ & 44 & 100 \\
- $\quad$ Agricultural Irrigation & & 72.0 \\
- Drinking-Water & & 14.0 \\
- Use of Industry & & 14.0 \\
\hline
\end{tabular}


billion $\mathrm{km}^{3}$ of this water goes back to the atmosphere by evaporation; 63 billion $\mathrm{km}^{3}$ leaks down to the underground, and 140 billion $\mathrm{km}^{3}$ reaches to the rivers, lakes, and seas by runoff. About 25 billion $\mathrm{km}^{3}$ of 63 billion $\mathrm{km}^{3}$ water that leaks down to the underground join back to surface water through springs. Only 44 billion $\mathrm{km}^{3}$ of approximately 189 billion $\mathrm{km}^{3}$ renewable water potential can be used in agriculture [17].

\subsection{Rivers}

Four of the river forms the watersheds in Turkey is reaching the sea beyond the country's borders. These are the Euphrates, Tigris, Coruh, and Aras rivers. The Euphrates and Tigris rivers are rises in the Eastern Anatolia region of Turkey. Then they flow through Syria and Iraq and reach the sea in the Persian Gulf. The Euphrates has a total length of $2800 \mathrm{~km}$ and only $971 \mathrm{~km}$ of the river is within Turkey's border. The Tigris has a total length of $1900 \mathrm{~km}$ of which $523 \mathrm{~km}$ lie within Turkey. Çoruh, one of the fastest rivers in the world, flows $431 \mathrm{~km}$ inland Turkey and after flowing $21 \mathrm{~km}$ before discharging into the Black Sea in Georgia.

The Aras river, one of the largest rivers of the Caucasus, is $1072 \mathrm{~km}$ long and reaches the Caspian Sea from Azerbaijan. Aras River rises in Turkey and after $300 \mathrm{~km}$ the river forms some countries' borders such as Turkey-Armenia and Azerbaijan-Iran border.

Other transboundary rivers are the Evros/Meriç River, which comes from Bulgaria and Greece and reaches the Aegean Sea, and the Asie River, which comes from Lebanon and Syria and reaches the Mediterranean [27].

Other rivers that make up the water basins are as follows. The length of Kizllırmak, the longest rivers reaching the Black Sea, is $1355 \mathrm{~km}$, Sakarya is 824 $\mathrm{km}$ and Yeşilırmak is $519 \mathrm{~km}$. The length of the Büyük Menderes from the river reaching the Aegean Sea is $548 \mathrm{~km}$, the Gediz River is $401 \mathrm{~km}$ and the Küçük Menderes is $175 \mathrm{~km}$. From the river reaching the Mediterranean, Seyhan is 560 $\mathrm{km}$, Ceyhan is $509 \mathrm{~km}$ and Göksu is $260 \mathrm{~km}$ long [16]. Turkey's territory has 25 major river basins showing a big change compared to the average annual rainfall, evaporation, and runoff characteristics [27]. Rivers and water basins in Turkey are given in Figure 3.

\subsection{Water Basins}

As shown the largest catchment areas are the Euphrates-Tigris, respectively, Kızilırmak, Sakarya and Konya inland basin (Table 2). The total drainage area of the Euphrates-Tigris basin is $184,918 \mathrm{~km}^{2}$. They provide $29.2 \%$ of the total surface water supply. Kizllırmak basin, the second largest basin, has a drainage area of $78.180 \mathrm{~km}^{2}$. Konya inland basin $\left(53,850 \mathrm{~km}^{2}\right)$, which is one of the major basins, is also among the basins with the least runoff.

\subsection{Groundwater}

The use of groundwater is an important alternative in places where surface water 


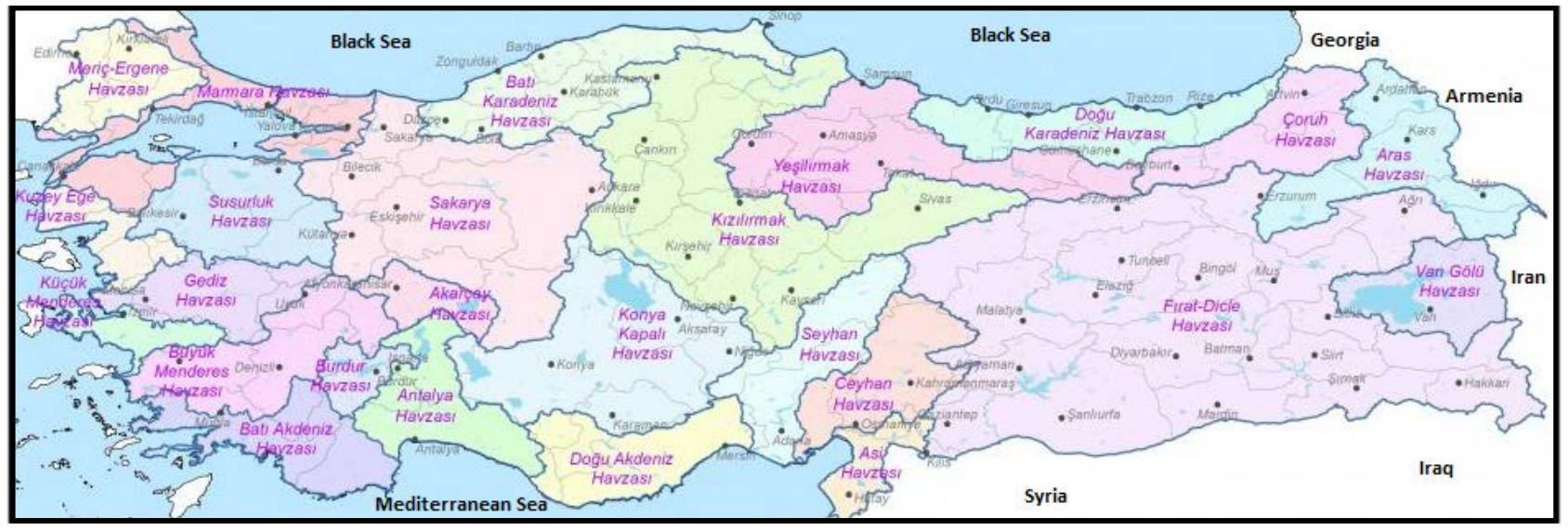

Figure 3. Water basins in Turkey [17].

Table 2. The average surface areas and water potential of the basins in Turkey (2020).

\begin{tabular}{|c|c|c|c|c|c|}
\hline $\begin{array}{l}\text { Basin } \\
\text { No }\end{array}$ & Basin name & $\begin{array}{l}\text { Precipitation } \\
\text { Area }\left(\mathrm{km}^{2}\right)\end{array}$ & $\begin{array}{c}\text { Mean annual } \\
\text { discharge }\left(\mathrm{km}^{3}\right)\end{array}$ & Rate (\%) & Draining to \\
\hline 1 & Meriç Ergene & 14.560 & 1.84 & 1.1 & From Bulgaria to the Aegean Sea \\
\hline 2 & Marmara & 24.100 & 7.54 & 4.4 & Sea of Marmara \\
\hline 3 & Susurluk & 22.399 & 4.23 & 2.5 & Sea of Marmara \\
\hline 4 & North Aegean & 10.003 & 1.5 & 0.9 & Aegean Sea \\
\hline 5 & Gediz & 18.000 & 1.54 & 0.9 & Aegean Sea \\
\hline 6 & Küçük Menderes & 6.907 & 0.53 & 0.3 & Aegean Sea \\
\hline 7 & Büyük Menderes & 24.976 & 2.97 & 1.7 & Aegean Sea \\
\hline 8 & West Mediterranean & 20.953 & 6.97 & 4.1 & Mediterranean Sea \\
\hline 9 & Antalya & 19.577 & 11.25 & 6.6 & Mediterranean Sea \\
\hline 10 & Burdur Lakes Area & 6.374 & 0.26 & 0.1 & Interior \\
\hline 11 & Akarçay & 7.605 & 0.33 & 0.2 & Interior \\
\hline 12 & Sakarya & 58.160 & 5.16 & 3 & Black Sea \\
\hline 13 & West Black Sea & 29.598 & 9.91 & 5.8 & Black Sea \\
\hline 14 & Yeşilırmak & 36.114 & 6.58 & 3.8 & Black Sea \\
\hline 15 & Kizılırmak & 78.180 & 6.12 & 3.6 & Black Sea \\
\hline 16 & Konya inland basin & 53.850 & 2.65 & 1.5 & Interior \\
\hline 17 & East Mediterranean & 22.048 & 11.25 & 6.6 & Mediterranean Sea \\
\hline 18 & Seyhan & 20.450 & 6.79 & 4 & Mediterranean Sea \\
\hline 19 & Ceyhan & 21.982 & 7.37 & 4 & Mediterranean Sea \\
\hline 20 & Asi (Orontes) & 7.796 & 0.89 & 0.5 & From Syria to Mediterranean Sea \\
\hline 21 & Euphrates and Tigris & 184.918 & 49.91 & 29.2 & To Syria/Iraq/the Persian Gulf \\
\hline 22 & East Black Sea & 24.077 & 14.93 & 8.7 & Black Sea \\
\hline 23 & Çoruh & 19.872 & 7.05 & 4.1 & To Georgia and the Black Sea \\
\hline 24 & Aras & 27.548 & 4.18 & 2.4 & To Azerbaijan and Caspian Sea \\
\hline \multirow[t]{2}{*}{25} & Van inland basin & 19.405 & 2.26 & 1.2 & Interior \\
\hline & Total & 779.452 & 171 & 100 & \\
\hline
\end{tabular}


is lacking for agricultural production. In Turkey, $78 \%$ of the irrigation water comes from surface sources and $22 \%$ from underground sources. Turkey throughout 1428 ha of land is irrigated by groundwater. The operation of groundwater investments made by the state in arid regions through irrigation cooperatives is being carried out successfully as an important model. Groundwater is densely extracted from wells drilled in Konya, Isparta, Eskişehir, Kayseri, Edirne, Samsun, and İzmir provinces and used for irrigation.

65 billion $\mathrm{km}^{3}$ of annual rainfall in Turkey (14\%) are infiltrated underground. 25 million $\mathrm{km}^{3}$ of this rise back to the ground as usable water with springs. There are 18 million $\mathrm{km}^{3}$ of water retractable from the underground [17]. The underground water investments for irrigation are costly to be used for opening the wells; setting up the motto-driven pumps, electrification to the facilities, and constructing canals and sheds for the facilities.

\section{Water Management and Irrigation Investments}

Water investments will need to be obtained from the coalition of different ministries in Turkey. For example, Ministry of Development from fund allocation according to development plans, Ministry of Agriculture-Forestry from the establishment of the cooperative irrigation, State Hydraulic Works from the establishment of surface and underground water facilities, Province specific government and SHW from the construction of the Irrigation channels and pipes are responsible. Universities, research institutes, and The Scientific and Technological Research Council of Turkey also make irrigation researches. However, as irrigation investments are generally made by SHW, it was deemed sufficient to evaluate SHW investments.

SHW invested the US\$ 60 billion in the period 1954-2018. In Figure 4, the

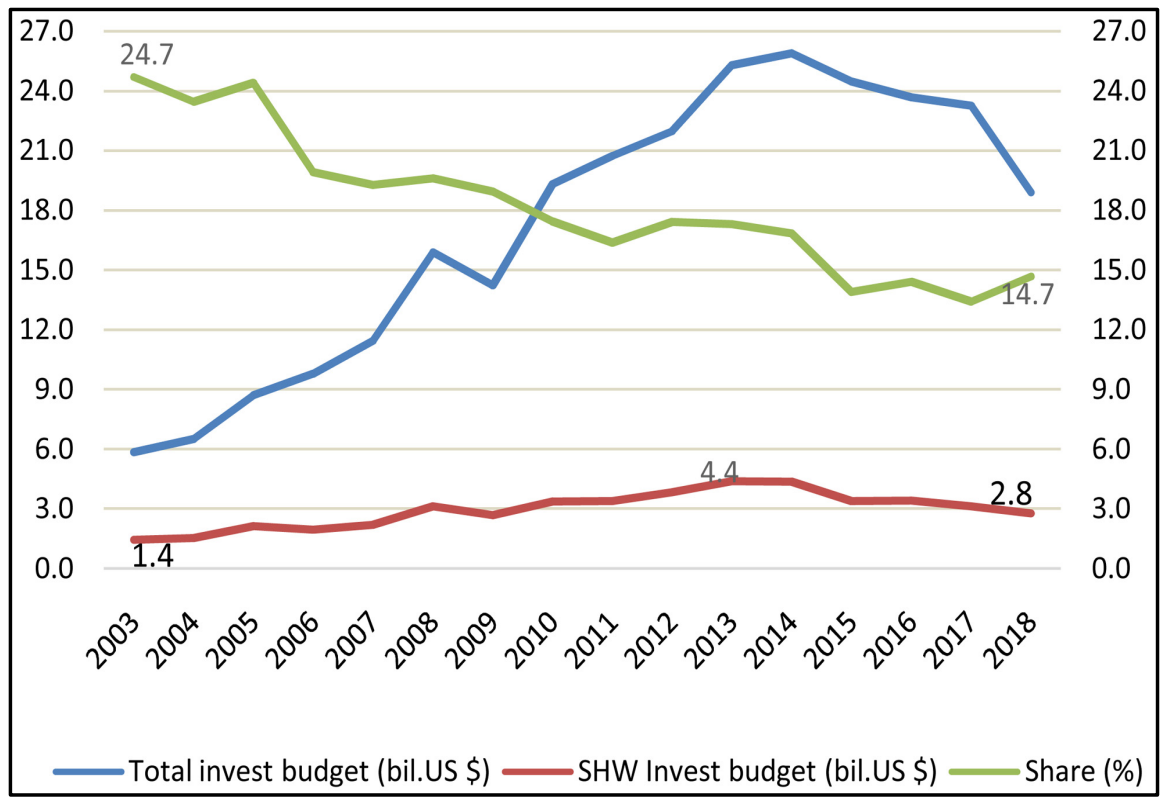

Figure 4. SHW budget and its change within the total investment budget (2003-2018). 
SHW budget and its change within the total investment budget are given between 2003-2018. Accordingly, the SHW investment budget, which was \$ 1.4 billion in 2003, increased to $\$ 4.4$ billion in 2013 , but it is seen that it decreased to $\$ 2.8$ billion in 2018 . The share of the SHW budget in the total budget has steadily decreased from $24.7 \%$ to $14.7 \%$ between $2003-2018$ [17]. From this figure, it is understood that change of investment priorities and loss of the priority of water investments after 2003 in Turkey.

Despite the potential for river and surface water resources, due to high investment costs and difficulties of the terrain topography, Turkey cannot benefit enough from this water potential for irrigation. The investment cost for small irrigation projects is 3000 US dollars/ha, while it is around 12,000 US dollars/ha for large irrigation projects (including pumping) [17].

One of the purposes of SHW's with the new investments is to change the current way of surface irrigation, which is done by canals having open tops. With the investments, these surface irrigation canals will be replaced with pipelines that might supply a much better job of transferring water without much loss.

The water transfer yields $70 \%$ in soil channels, $85 \%$ in the concrete channel while in pipelines can rise to $100 \%$. Irrigation efficiency in the field is $60 \%$ in surface irrigation, $80 \%$ in sprinkler irrigation, and $90 \%$ in drip irrigation [29]. Water loss is $15 \%$ in water transfer with open the concrete channel systems. The water losses from irrigation systems lead to problems such as drainage and salinity that cannot be solved easily in short term. Therefore, the salinization of the agricultural lands has negative impacts on the yield, production, and consequently on food security [30].

To improve the water use efficiency as one of the preferred strategies in the food and water security, transforming the existing systems to the modern irrigation ones should be the essential action also to meet public food demand as well as their welfare. Saving water by using modern irrigation systems can also help to balance the water shared by sectors like agriculture and industry. The fact that Turkey is not a water-rich country increases the significance of this transformation. That's why while the low-pressure concrete pipes were started to be produced after the 1980s, and high-pressure irrigation systems were started to be built in the 2000s. Extensive irrigation projects in Turkey are run by SHW. By 2023 the SHW is targeting to finish the irrigation investments for 2.1 million ha of farmland [17].

It has been determined that the Euphrates-Tigris basin is one of the most irrigable basins with dry farming. It is followed by the Konya inland basin. For this reason, SHW irrigation investment projects are concentrated in these two basins.

\subsection{Southeastern Anatolian Project}

Southeastern Anatolia Project (GAP) is located in the Euphrates-Tigris river basin, covering Adıyaman, Batman, Diyarbakır, Gaziantep, Kilis, Mardin, Siirt, Şanlıurfa, and Şırnak nine provinces having approximately $10 \%$ of the total 
population and area of Turkey. The main objective of GAP 20\% of Turkey's irrigable land ( $1.7 \mathrm{~m} \mathrm{ha})$ of fertile soil that makes up Southeast Anatolia with the Euphrates and Tigris rivers to irrigate. Only $30 \%$ of the irrigable areas in the Region have been opened to irrigation. With this project, it is aimed to open the remaining $70 \%$ ( $1.1 \mathrm{~m} \mathrm{ha}$ ) to irrigation. Within the scope of the GAP Project, the construction of 20 irrigation projects, which will irrigate 279,000 ha of land, continues [17].

According to a study, It was seen that wheat areas decreased, while corn and cotton areas increased along with putting into practice the irrigation in the region. Gross production value is defined as an increase of $84 \%$ per hectare [31].

\subsection{Konya Plain Project}

Konya Plain Project (KOP) is implemented in the Konya inland basin with an area of three $m$ ha in the Central Anatolia Region. The KOP project covers eight provinces consisting of Konya, Aksaray, Karaman, Niğde, Kırıkkale, Kırşehir, Nevşehir, and Yozgat. With the project, $1.1 \mathrm{~m}$ ha of land was planned to be irrigated and 397,000 ha (36\%) of land were opened to irrigation so far. About $25 \%$ is irrigated with groundwater by irrigation cooperatives. The remainder (31\%) also is at the investment or project stage. After the GAP, It is the largest irrigation investment project in Turkey [17].

Because the groundwater is intensely used in the region, the groundwater levels of the wells are gradually falling down. The most important benefit of the KOP project will be recharging artificially groundwater reservoirs by diverted water supply from the neighbor watersheds. According to a survey conducted in the irrigated area, the average wheat yield of $2300 \mathrm{~kg} / \mathrm{ha}$ has been identified that of increase to $4300 \mathrm{~kg} / \mathrm{ha}$ [32].

Irrigating the dry agricultural lands may ensure reducing the fallowed areas that will increase crop yield and change the crop pattern towards the industrial crops as a response. At the completion of the project wheat production and accordingly yield is estimated to increase $87 \%$, which will be a significant contribution to food security.

\subsection{East Anatolian Project}

East Anatolian Project (DAP) involved in 15 provinces covers $23 \%$ of the surface area of Turkey. Within the scope of the project, it is planned to irrigate $1.4 \mathrm{~m}$ ha of agricultural land in the region. With the DAP Project, 35 irrigation projects have been completed and 525,000 ha (37\%) of land has been opened to irrigation. Investments in 44 irrigation projects are also continuing [17].

According to a survey conducted in Erzurum, the average wheat yield of 3780 $\mathrm{kg} / \mathrm{ha}$ has been identified that as an increase to $4960 \mathrm{~kg} / \mathrm{ha}$ [33]. At the completion of the project improved irrigation, and enlarged irrigated areas in the region will increase the wheat yield by $31 \%$ as a significant contribution to food security. 


\subsection{Other Irrigation Projects}

Eastern Black Sea Project (DOKAP) has nine provinces and constituting 7.5\% of the surface area of Turkey. These provinces are Samsun Tokat, Giresun, Istanbul, Ordu, Gümüşhane, Bayburt, Rize, and Artvin. $41 \%$ of the irrigation projects in the region are completed, $17 \%$ are at the construction stage, and $42 \%$ are at the planning or project stage.

Thrace Development Project (TRAGEP) covers the provinces of Edirne, Kırklareli, Tekirdağ, and Çanakkale. Within the scope of the project, 89 projects were completed in the 2003-2020 period and 137,000 ha of land started to be irrigated [17].

\subsection{Irrigation Subsidies for Farmers}

The Ministry of Agriculture and Forestry (MoAF) donates 50\% of the cost of investment to the modern-irrigation systems to extend the use of newer techniques among the farmers. It is highly appreciated by the farmers as well that these new systems are significantly more efficient than the older systems. According to MoAF, even with the 50\% financial incentive, some farmers are not able to start investments due to limited capital sources. A subsidy loan program of which the interests for the loans are subsidized by the MoAF has started to help these farmers to overcome the limited capital source difficulties.

MoAF has seen land consolidation as a tool to accelerate irrigation investments and reduce costs in recent years. Combining land consolidation with irrigation projects saves $40 \%$ on irrigation investments. When agricultural production is carried out on dry land, small and scattered parcels, costs increase. The Turkish government has proposed a number of changes in how inheritance rights will be managed in the land consolidation and irrigation program [34].

\subsection{Farmer Irrigation Organizations}

After 1993, SHW transferred the maintenance and management of irrigation canals that deliver water to approximately $2 \mathrm{~m}$ ha of land to local administrations (village authorities or municipalities) and water user associations [26]. Irrigation investment of SHW in Turkey is generally operating by irrigation associations (372), cooperatives (269), municipalities (143), and village authorities (189).

Irrigation associations and cooperations decide on the following matters: the starting date of irrigation; the ending date of irritation; the order of irrigation and the price of irrigation. The dates of irrigation will be declared to the farmers in advance. These are also responsible for maintenance services.

The most significant cost factor for underground water irrigation cooperations is energy. The share of energy costs in total production costs according to plant varieties and irrigation methods can rise up to $17 \%$ [35]. The irrigation cost is collected at the end of the harvesting season. But farmers are not willing to pay the price of energy. So energy debt accumulates and leads to various 
problems every year. The payment willingness of energy costs has been found to decrease depending on a young age and small family [36].

Irrigation cooperatives (1458) irrigate 497,000 ha of land with groundwater. The provinces that provide the most irrigation with groundwater are Eskişehir (192,000 ha), Isparta (72,000 ha), Izmir (38,000 ha), Aydın, Bursa, Diyarbakır, Adana, and Edirne.

\section{Agriculture and Food Security}

Eradication of hunger and poverty and ensuring environmental sustainability are among Millennium Development Goals of FAO [13]. Turkey has 24 million hectares of arable land. While $15.4 \mathrm{~m}$ ha $(66.7 \%)$ of this is cultivated, $3.4 \mathrm{~m}$ ha (14.7\%) is left fallow [37].

\subsection{The Effect of Irrigation on Production}

Climate and irrigation possibilities are the two major factors, which affect land use in all regions, directly [38]. According to SHW calculations, $12 \mathrm{~m}$ ha of agricultural land in Turkey can be irrigated by modern irrigated systems. However, only $6.4 \mathrm{~m}(53.3 \%)$ of the irrigable land has been opened for irrigation. Water consumption in agriculture is predicted to increase from 43 billion $\mathrm{km}^{3}$ to 64 billion $\mathrm{km}^{3}$ depending on the expansion of irrigated areas. However, considering the increasing water demand of other sectors, it is estimated that the share of agriculture in total water use will decrease from $72 \%$ to $64 \%$ [17].

The crop pattern where the lands are opened to irrigation has been completely changed from monoculture production into polyculture production. As a consequence, crop yield, accordingly, farmers' income is increasing markedly. While cereals (wheat, barley) are produced and fallow are made in dry agriculture, the production pattern in irrigated agriculture is sugar beet, corn, cotton, wheat, vegetables, and fruits. Grain yield in irrigated areas increased to an average of 4.6 tons/ha, cotton to 4 tons/ha, corn to 12 tons/ha. With irrigation, yield increase was achieved in cereals by $166 \%$, in legumes $239 \%$, in sugar beet $95 \%$, in cotton $292 \%$, in corn $564 \%$, in fruit $117 \%$, in citrus $130 \%$ and in vegetables $134 \%$. While the production value in dry agriculture due to rainfall was $1990 \mathrm{TL} / \mathrm{ha}$ on average, it increased to $11,850 \mathrm{TL} / \mathrm{ha}$ with irrigation. The contribution of irrigated agriculture $(6.4 \mathrm{~m} \mathrm{ha})$ to food security in Turkey is calculated as $2 / 3$. In other words, Turkey's agricultural production $2 / 3$ is made in irrigated areas [17].

The Turkish government, which foresees that irrigation in arid areas is of vital importance in terms of food security, has planned to open 8.5 million hectares of cultivated land to irrigation by 2023 and targeted the Gross Agricultural Production Value as 150 billion US \$ [39]. However, since the necessary irrigation investments could not be made, it is not considered possible to reach the targets set by the government. Developments regarding agricultural production value according to TURKSTAT data are given in Figure 5.

The agricultural production value in Turkey, while US \$ 37.4 billion in 1998, 


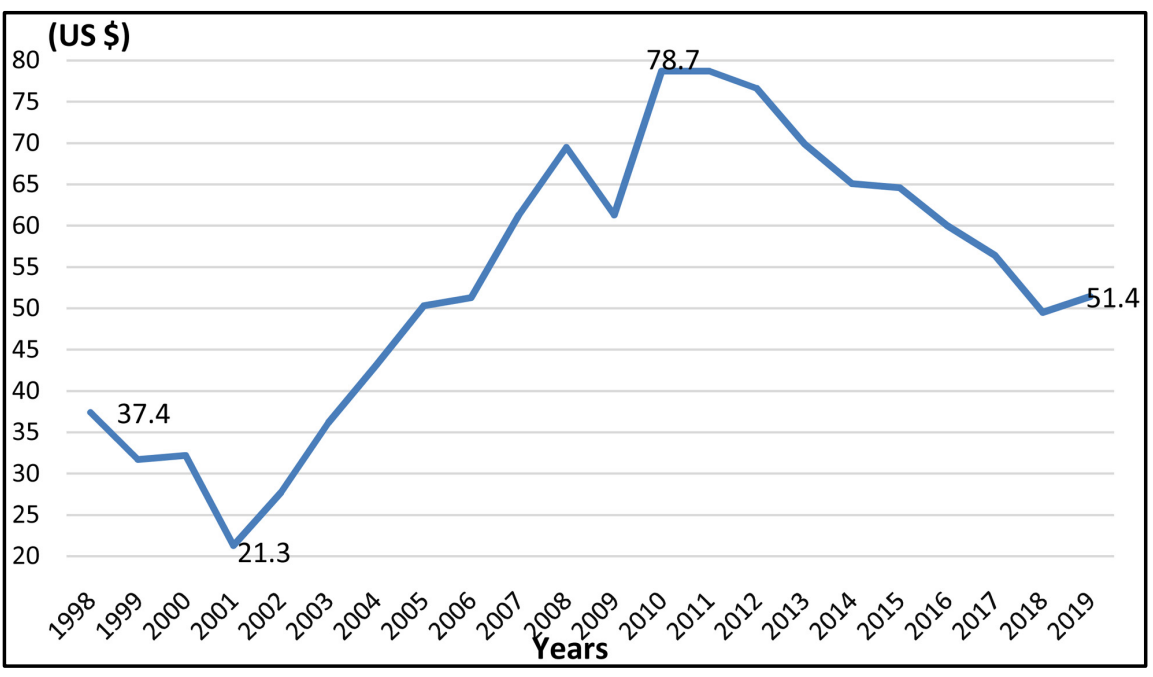

Figure 5. The agricultural production value in Turkey (billion US \$).

US $\$ 21.3$ billion in 2001 with the economic crisis' has fallen. Production value then increased rapidly and reached US $\$ 78.7$ billion in 2010 . However, due to the depreciation of the Turkish lira, it decreased to US \$ 51.4 billion in 2019. It is seen that the agricultural production value decreased after the year 2010. This situation is evaluated as a result of the reflection induced by macroeconomic factors and climate change effects on agriculture in Turkey [40].

\subsection{Food Sufficiency Balance}

Turkey's self-sufficiency rate in food security is given in Table 3. Generally, wheat, sugar, fruits (except walnuts), and vegetables are sufficiently produced from agricultural products. However, especially corn, sunflower, rape, dry bean, and lentil cannot be produced sufficiently. Even in the last ten years, the insufficiency of legumes has increased. In the 2007-2017 period, there was a $26 \%$ increase in sunflower production in self-sufficiency rates, and a decrease of $31.2 \%$ and $34.9 \%$ in chickpea and red lentil production, respectively [37]. While the self-sufficiency rates of citrus fruits and grapes increased in the fruit group, there was no significant change in the vegetable group.

\section{Conclusions and Recommendation}

Turkey is emerging as a need for irrigation in agricultural areas because it has a semi-arid climate. As it is not a country rich in water resources, it cannot benefit sufficiently from the existing surface water resources. Since 1963, Irrigation investments were prioritized when the planned period of development began. After the 2000s, the share allocated to irrigation investments from the general budget started to decrease. SHW, which previously declared irrigable areas as 8.5 $\mathrm{m}$ ha, revised this figure to $12 \mathrm{~m}$ ha with pressurized irrigation investments. The government aimed to irrigate an area of approximately $2.1 \mathrm{~m}$ ha with the Southeastern Anatolia Project, Konya Plain Project, and Eastern Black Sea Projects. It 
Table 3. Self-Sufficiency rate of agricultural products in Turkey (2017).

\begin{tabular}{cccccc}
\hline Product Group & Self-Sufficiency Rate (\%) & Product Group & \multicolumn{2}{c}{$\begin{array}{c}\text { Self-Sufficiency } \\
\text { rate (\%) }\end{array}$} \\
\hline $\begin{array}{c}\text { Cereal, Oilseeds \& } \\
\text { Dried pulses }\end{array}$ & 2007 & 2017 & $\begin{array}{c}\text { Fruits, } \\
\text { Vegetables }\end{array}$ & 2007 & 2017 \\
\hline Wheat & 96.5 & 111.7 & Mandarin & 159.2 & 194.5 \\
Barley & 97.3 & 90.2 & Orange & 108.7 & 197.9 \\
Corn & 81.4 & 73.3 & Lemon & 157.8 & 241.6 \\
Sunflower & 38.3 & 64.3 & Grape & 138.1 & 153.8 \\
Rapeseed & 8.4 & 70.3 & Apple & 120.0 & 127.5 \\
Rice & 60.5 & 67.2 & Apricot & 802.1 & 391.5 \\
Dried beans & 70.9 & 82.7 & Hazelnut & 993.2 & 501.7 \\
Chickpea & 118.7 & 87.5 & Walnut & 81.0 & 74.5 \\
Red lentils & 124.5 & 89.6 & Tomato & 111.5 & 110.7 \\
Green lentils & 50 & 56.5 & Pepper & 110 & 109.2 \\
Tea & 99.5 & 93.2 & Potato & 104.6 & 103.5 \\
Sugar & 97.8 & 116.1 & Onion & 111.2 & 108.2 \\
\hline
\end{tabular}

has been calculated that the contribution of this area to be irrigated to agricultural production and food security will increase by approximately $80 \%$ compared to dry agriculture. However, it seems impossible to reach the 2023 targets as sufficient financial resources cannot be allocated.

On the other hand, although the total amount of agricultural production did not decrease, it is observed that the total agricultural gross product started to decrease in US dollars after 2010 due to the developments in the macroeconomy. Fruit and vegetable production and self-sufficiency rates have developed positively in the last 10 years, but especially pulses production has shown a negative development. According to the cause and effect analysis made with the fishbone diagram, it was seen that the most effective factor in food insecurity was irrigation. Therefore, irrigation investments should be accelerated and irrigated areas should be expanded before the negative effects of possible climate change in food security emerge in the region. On the other hand, it is recommended that the Ministry of Agriculture and Forestry increases its financial support to modern irrigation systems, harmonizes the basin-based support system with SHW basins, updates the plant irrigation guide according to the product pattern and expands irrigation training.

\section{Acknowledgements}

The authors would like to express appreciation for the provided data for this study by colleagues.

\section{Conflicts of Interest}

The authors declare no conflicts of interest regarding the publication of this paper. 


\section{References}

[1] Rosegrant, M.W., Cline, S.A. and Valmonte-Santos, R.A. (2010) Global Water and Food Security: Megatrends and Emerging Issues. In: Ringler, C., Biswas, A. and Cline, S., Eds., Global Change: Impacts on Water and Food Security, Water Resources Development and Management, Springer, Berlin, Heidelberg, 14-47. https://doi.org/10.1007/978-3-642-04615-5 2

[2] Zhang, X., Guo, Q., Shen, X., Yu, S. and Qiu, G. (2015) Water Quality, Agriculture and Food Safety in China: Current Situation, Trends, Interdependencies, and Management. Journal of Integrative Agriculture, 14, 2365-2379. https://doi.org/10.1016/S2095-3119(15)61128-5

[3] Chowdhury, N.T. (2010) Water Management in Bangladesh: An Analytical Review, Water Policy, 12, 32-51. https://doi.org/10.2166/wp.2009.112

[4] Li, J., Ma, W., Renwick, A. and Zheng, H. (2020) The Impact of Access to Irrigation on Rural İncomes and Diversification: Evidence from China. China Agricultural Economic Review, 12, 705-725. https://doi.org/10.1108/CAER-09-2019-0172

[5] Huang, Q., Rozelle, S., Lohmar, B., Huang, J. and Wang, J. (2006) Irrigation, Agricultural Performance, and Poverty Reduction in China. Food Policy, 31, 30-52. https://doi.org/10.1016/j.foodpol.2005.06.004

[6] Kiprutto, N., Rotich, L.K. and Riungu, G.K. (2015) Agriculture, Climate Change, and Food Security. Open Access Library Journal, 2, e1472.

https://doi.org/10.4236/oalib.1101472

[7] Zhu, X.K. (2012) National Food Security Strategy from the Perspective of Modern Agricultural Development. (In Chinese) http://www.npc.gov.cn/npc/xinwen/2012-07/06/content 1729123.htm

[8] Kesuma, S.I., Maryunianta, Y. and Muda, I. (2018) Evaluation of İrrigation System to Support the Implementation of Food Security Policy. International Journal of Civil Engineering and Technology, 9, 600-614 http://www.iaeme.com/ijciet/issues.asp? Type=IJCIET\&VType=9\&IType $=9$

[9] Wang, J., Zhu, Y., Sun, T. and Huang, Q. (2020) Forty Years of Irrigation Development and Reform in China. Australian Journal of Agricultural and Resource Economics, 64. https://doi.org/10.1111/1467-8489.12334

[10] Maitra, S. and Pine, S. (2020) Smart Irrigation for Food Security and Agricultural Sustainability. Indian Journal of Natural Sciences, 10, 20435-20439. https://www.researchgate.net/publication/342109279

[11] Huang, J. and Rozelle, S. (2018) China's 40 Years of Agricultural Development and Reform-China's 40 Years of Reform and Development: 1978-2018. 487-506. https://doi.org/10.22459/CYRD.07.2018.24

[12] Headey, D. and Fan, S. (2010) Global Food Crisis. International Food Policy Research Institute, Washington DC, 46-49.

[13] Frenken, K. (2009) Irrigation in the Middle East Region in Figures AQUASTAT Survey-2008. FAO Water Reports, 34, 355-375.

http://www.fao.org/3/a-i0936e.pdf

[14] Mandara, C.G., Butijn, C. and Niehof, A. (2013) Community Management and Sustainability of Rural Water facilities in Tanzania. Water Policy, 15, 79-100. https://doi.org/10.2166/wp.2013.014

[15] Jiménez, A. and Pérez-Foguet, A. (2010) Building the Role of Local Government Authorities towards the Achievement of the Human Right to Water in Rural Tanzania. Natural Resources Forum, 34, 93-105. 
https://doi.org/10.1111/j.1477-8947.2010.01296.x

[16] Wikipedia (2020) https://tr.wikipedia.org/wiki/Süleyman Demirel

[17] SHWa (2020) Devlet Su İşleri Genel Müdürlüğü 1954-2018: Su ve DSI. https://dsi.gov.tr/Sayfa/Detay/754\#

[18] Ilie, G. and Ciocoiu, C.N. (2010) Application of Fishbone Diagram to Determine the Risk of an Event with Multiple Causes. Management Research And Practice, 2, 1-20. https://www.researchgate.net/publication/46567642

[19] GDM (2020) Türkiye Geneli Alansal Yağışlar. https://www.mgm.gov.tr/veridegerlendirme/yillik-toplam-yagis-verileri.aspx

[20] IPCC (2007) Climate Change 2007 Synthesis Report. https://www.ipcc.ch/site/assets/uploads/2018/02/ar4 syr full report.pdf

[21] Kamber, R., Baştuğ, R., Büyüktaş, D., Ünlü, M. and Kapur, M. (2010) Impact on Agricultural Irrigation and Water Sources of Global Climate Change. Agriculture Engineering VII. Technic Congress, Ankara, 11-15 January 2010.

[22] SHWb (2011) Türkiye'nin İklim Değişikliği Uyum Stratejisi ve Eylem Planı. https://webdosya.csb.gov.tr/db/iklim/editordosya/uyum stratejisi eylem plani TR. pdf

[23] MoAf (2020) National Water Plan 2019-2023. https://www.tarimorman.gov.tr/SYGM/Belgeler/NHYP\%20DEN\%C4\%B0Z/ULUS AL\%20SU\%20PLANI.pdf

[24] MoEU (2020) National Climate Change Action Plan 2011-2023. https://webdosya.csb.gov.tr/db/iklim/editordosya/file/eylem\%20planlari/Iklim\%20 Degisikligi\%20Eylem\%20Plani TR.pdf

[25] WB (2015) World Bank Group Turkey Partnership: Country Program. http://www.worldbank.org/content/dam/Worldbank/document/eca/Turkey-Snapsh ot.pdf

[26] Kibaroğlu, A. and Başkan, A. (2011) Turkey’s Water Policy Framework. In: Kibaroğlu, A., Scheuman, W. and Kramer, A., Eds., Turkey's Water Policy National Frameworks and International Cooperation, Springer-Verlag, Berlin, Heidelberg, 3-25. https://doi.org/10.1007/978-3-642-19636-2 1

[27] Tigrek, S. and Kibaroglu, A. (2011). Strategic Role of Water Resources for Turkey. In: Kibaroğlu A., Scheuman, W. and Kramer, A., Eds., Turkey's Water Policy National Frameworks and International Cooperation, Springer-Verlag, Berlin, Heidelberg, 27-42. https://doi.org/10.1007/978-3-642-19636-2 2

[28] Gürer, I. (2007) Global Warming, Water Sources of Turkey, Possible Interaction. Turkey 1 st Climate Change Congress, Istanbul, 11-13 April 2007, 8-27.

[29] Güngör, Y., Erözel, A.Z. and Yıldırım, O. (2004) Irrigation. 3rd Edition, Ankara University Agriculture Faculty No: 1540, Lesson Book, Ankara. (In Turkish)

[30] Sönmez, B. (2008) Guide of Aridity Control. Ministry of Food, Agriculture and Livestock, Soil, Fertilizer and Water Sources Center Research Institute, Technical Publication No. 33, Ankara. (In Turkish)

[31] Pıçak, M. (2008) The Crop Production Development of the Southeastern Anatolian Region Project Region on The Basis of the Economical Indicators. National Crop Symposium, Konya, 2-5 June 2008, 667-673.

[32] Özdemir, F., Küçükçongar, M. and Kan, M. (2013) Determining the Prevalence of Wheat Varieties in Konya Province, I. KOP Regional Development Symposium, Konya, 14 November 2013, 186-193. 
[33] Sevim, Z. (1988) Erzurum Terms of Wheat Water Consumption. General Directorate of Rural Affairs, Research Institute Publications, Erzurum.

[34] Yücer, A., Kan, M., Demirtaş, M. and Kalanlar, Ş. (2016) The Importance of Creating New Inheritance Policies and Laws That Reduce Agricultural Land Fragmentation and İts negative İmpacts in Turkey. Land Use Policy, 56, 1-7.

https://doi.org/10.1016/j.landusepol.2016.04.029

[35] Kodal, S., Yıldırım, Y.E. and Demir, H. (2005) Farmers Participation in the Management of Public Irrigation Schemes in Turkey. (Unpublished FAO Country Paper)

[36] Aydoğdu, M. and Karlı, B. (2016) Analysis of Factor Affecting Willingness to Pay for Agricultural Irrigation under Water Shortages-GAP Harran Plain Samplings. XII Tarım Ekonomisi Kongresi Bildirileri, Isparta. (In Turkish)

[37] TURKSTAT (2020) Crop Production Statistics. https://data.tuik.gov.tr/Kategori/GetKategori?p=tarim-111\&dil=2

[38] Yücer, A. (2020) The Land Use in Turkey: A General Assessment and Affecting Factors. Journal of Geoscience and Environment Protection, 8, 102-116.

https://doi.org/10.4236/gep.2020.810007

[39] Davutoğlu, A. (2014) 62th Government Programme of the Turkish Republic. https://www.tbmm.gov.tr/develop/owa/Tutanak B SD.birlesim baslangic yazici?P $\underline{4=22237 \& \mathrm{P} 5=\mathrm{H} \text { \&page } 1=1 \text { \&page } 2=20}$

[40] Yavuz, F. (2014) The Reasons of Decline in Agriculture, 8 December 2014. http://www.aljazeera.com.tr/gorus/tarimda-kuculmenin-nedenleri 